\title{
Non-pharmacological therapies applied in pregnancy and labor: an integrative review
}

\author{
Terapias não farmacológicas aplicadas na gestação e no trabalho de parto: revisão integrativa \\ Terapias no farmacológicas aplicadas en el embarazo y el parto: una revisión integradora
}

How to cite this article:

Biana CB, Cecagno D, Porto AR, Cecagno S, Marques VA, Soares MC. Non-pharmacological therapies applied in pregnancy and labor: an integrative review. Rev Esc Enferm USP. 2021;55:e03681. doi: https://doi.org/10.1590/S1980-220X2019019703681

\section{Camilla Benigno Biana ${ }^{1}$ \\ Diana Cecagno ${ }^{1}$ \\ Adrize Rutz Porto ${ }^{1}$ \\ Susana Cecagno ${ }^{1}$ \\ Vanessa de Araujo Marques ${ }^{1}$ \\ Marilu Correa Soares ${ }^{1}$ \\ ${ }^{1}$ Universidade Federal de Pelotas, \\ Faculdade de Enfermagem, Departamento de Enfermagem, Pelotas, RS, Brazil.}

\begin{abstract}
Objective: To identify non-pharmacological therapies applied during pregnancy and labor. Method: Integrative review conducted in the databases: PubMed, ScieLO and PEDro, searching for articles from 2008 in English, Spanish and Portuguese. The descriptors used were: pregnancy, childbirth, physiotherapy, alternative and complementary medicine, alternative therapy, non-pharmacological therapy biomechanical therapy. Results: Forty-one articles were analyzed and subdivided into ten categories of nonpharmacological therapies: massage, perineal massage, hot bath, supportive care, childbirth preparation group, breathing techniques, pelvic floor exercises, transcutaneous electrostimulation, Swiss ball and spontaneous pushing. Six articles $(60 \%)$ showed a positive outcome for reduction of pain in labor and all of them had a positive outcome for different variables of labor, such as reduction of time, anxiety and pelvic floor laceration rates. Conclusion: The use of non-pharmacological therapies was efficient to reduce the effects of labor and childbirth, such as pain, duration of labor, anxiety, laceration and episiotomy.
\end{abstract}

DESCRIPTORS

Complementary Therapies; Exercise Therapy; Pregnancy; Natural Childbirth; Obstetric Nursing; Review. 


\section{INTRODUCTION}

The literature has different denominations for unconventional therapeutic practices in pregnancy, such as active movement, breathing exercises, use of the Swiss ball, massage, hot baths, among others, which are called: Non-Pharmacological Therapies (NPT), complementary medical therapies, alternative therapies, physiotherapeutic resources and manual therapies ${ }^{(1-2)}$. However, the first two terms are the most used when describing biomechanical and psychological therapies to reduce pain, increase mobility and facilitate labor ${ }^{(1)}$.

Basically, there are two groups of NPT used in pregnancy and labor: those involving application to soft or myofascial tissues (massage, myofascial release, acupressure, reflexology, Transcutaneous Electrostimulation - TENS, acupuncture, hot baths, ice application, perineal massage, breathing exercises, muscle relaxation) and those involving joint manipulation (bone mobilization, osteopathy, active free exercises, coordinated position changes, use of the Swiss ball ${ }^{(3-5)}$. The literature has demonstrated the benefits of these therapies for women in the pregnancy-childbirth process and similar positive results between therapies ${ }^{(6)}$.

In the perspective of knowing the NPT used in pregnancy and labor for promoting comfort and independence to the parturient woman, it is necessary to identify the scientific production addressing its use in the context of care to pregnant and parturient women. The choice for an integrative review is justified by the search for studies evaluating the use of NPT in a qualitative and quantitative perspective, in order to know quantitative scientific evidence and pregnant women's experiences with NPT. In this review, a search for NPT accessible to all health professionals, from their academic background, was performed, so that the results of this study allow any professional working in the maternal and child context to assist in the comprehensive care of pregnant women by using NPT with evidence of effective results.

Although the literature has reviews evaluating the use of certain NPT, such as TENS, massage, perineal massage and hot bath, no studies combining NPT and their effects in the support to pregnancy, labor and childbirth have been found $^{(1,7-9)}$. Thus, the objective of the study was to identify all of them and analyze them together.

\section{METHOD}

\section{TYPE OF STUDY}

This is an integrative review that followed the phases structured by Christmals and Gross ${ }^{(10)}$ in the conceptual, empirical, interpretative and communicative steps. The research question was developed, the inclusion and exclusion criteria were outlined, the literature search was performed and a data collection tool was adopted, followed by the categorization and evaluation of studies and interpretation of results ${ }^{(10)}$.

\section{SELECTION CRITERIA}

The guiding question was: what is the scientific production on NPT applied during pregnancy and labor and the possible results in labor and postpartum? The articles were selected according to the following criteria: published between 2008 and 2018 in English, Spanish and/or Portuguese. The following were excluded: literature reviews; studies that presented unsupervised physical exercises, aerobic, resistance and/or hypertrophy exercises and physical activity as therapies; and studies addressing therapies that required complementary training such as acupuncture, acupressure, osteopathy, chiropractic, Pilates and yoga.

\section{Data collection}

The literature search was performed in June 2018. The selected databases were: Publisher Medline (PubMed), Scientific Electronic Library Online (SciELO) and Physiotherapy Evidence Database (PEDro). Given the particularities of each database, the search was performed differently in each of them. In PubMed, the Medical Subject Heading (MeSH) terms were used: pregnancy (or) labor (and) physical therapy (and) complementary and alternative medicine, alternative therapy; nonpharmacological therapy; biomechanical therapy.

The SciELO search used the same Boolean descriptors and operators with its variations in Portuguese: gravidez, parto, fisioterapia, medicina alternativa e complementar, terapia alternativa, terapia não farmacológica, terapia biomêcanica; and in Spanish: embarazo, parto, fisioterapia, medicina alternativa y complementaria, terapia alternativa, terapia no farmacológica, terapia biomécanica.

The search in PEDro was performed according to the advanced search system of the database. The controlled descriptors 'pregnancy' and 'labor' were correlated to the following therapies using the Boolean operator 'AND': education, electrotherapies, heat and cold; hydrotherapy, balneotherapy; skill training; stretching, mobilization, manipulation, massage, respiratory therapy.

The articles were analyzed using the reference management tool Endnote version X7, duplicate articles were excluded, as well as those that did not answer the guiding question of the study or fit the exclusion criteria. Subsequently, abstracts were read and articles that met the inclusion criteria were selected for full reading.

\section{Data ANALYsis AND treatment}

The selected articles were analyzed and the categories of interventions were raised and discussed. Data analysis was based on the principles of Whittemore and Knaf( ${ }^{(11)}$ and performed according to the following steps: reduction of material, display of results, comparison, conclusion and verification $^{(10-11)}$.

\section{RESULTS}

The flowchart described in Figure 1 shows the process of selection of publications. Fifty-one articles were analyzed in full; five out of these were excluded for analyzing the results during pregnancy, three for not reporting the intervention, and two for being interventions applied in the puerperal 
period. At the end of the analysis, 41 articles remained, which were analyzed and subdivided into categories.

Ten NPT were identified in the studies of this review: massage, perineal massage, hot bath, supportive care, childbirth preparation group, breathing techniques, Pelvic Floor (PF) exercises, TENS, Swiss ball and spontaneous pushing. The description of studies is shown in Chart 1. The outcomes and variables assessed in the studies are described in Chart 2.

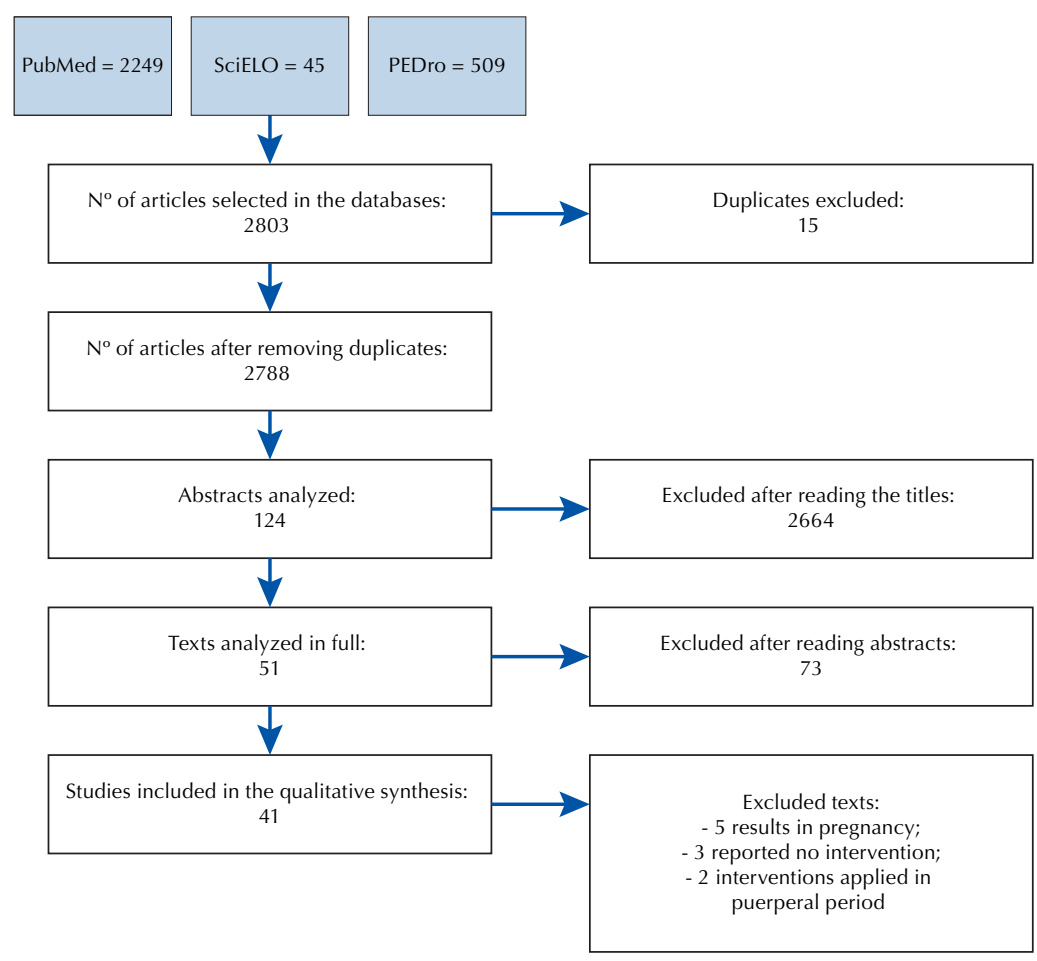

Legend: $\mathrm{N}^{\circ}=$ number

Figure 1 - Flowchart describing the selection of articles.

Chart 1 - Description of the integrative review studies.

\begin{tabular}{|c|c|c|c|}
\hline Authors & Profession of therapist & Study location & Methodological design \\
\hline Kimber, et al; $2008^{(12)}$ & Midwives and therapists & Prenatal centers & Randomized pilot study \\
\hline Mei-dan, et al; $\mathbf{2 0 0 8}^{(13)}$ & Midwives and self applicable & Prenatal clinics and maternity & Controlled clinical study \\
\hline Bergstrom, et al; $2009^{(14)}$ & Midwives & Prenatal clinics & Randomized clinical trial \\
\hline Davim, et al; $2009^{(3)}$ & Nurse & Maternity & Clinical intervention study \\
\hline Bahadoran, et al; 2010 ${ }^{(15)}$ & Not informed & Public health centers & Quasi-experimental clinical study \\
\hline Peng, et al; 2010 ${ }^{(16)}$ & Nurse & Maternity & Non-randomized clinical study \\
\hline Taghinejad, et al; 2010 ${ }^{(17)}$ & Midwives & Maternity & Randomized clinical trial \\
\hline Dias, et al; $2011^{(18)}$ & Physiotherapists & Maternity & Randomized clinical trial \\
\hline Gau, et al; $2011^{(19)}$ & Midwives & Maternity & Randomized clinical trial \\
\hline Geranmayeh, et al; $2011^{(20)}$ & Midwives & Maternity & Randomized clinical trial \\
\hline Dhany, et al; $2012^{(6)}$ & Not informed & Maternity & Retrospective clinical study \\
\hline Karacam, et al; 2012 211$)$ & Nurses and midwives & Maternity & Randomized clinical trial \\
\hline Low, et al; $2012^{(22)}$ & Nurses & Maternity & Randomized clinical trial \\
\hline Mortazavi, et al; $2012^{(23)}$ & Not informed & Maternity & Randomized clinical trial \\
\hline Ismail, et al; $2013^{(24)}$ & $\begin{array}{c}\text { Obstetrician, midwives and } \\
\text { physiotherapists }\end{array}$ & Maternity & Descriptive study \\
\hline Gallo, et al; $2013^{(25)}$ & Physiotherapist & Maternity & Randomized clinical trial \\
\hline
\end{tabular}




\begin{tabular}{|c|c|c|c|}
\hline Authors & Profession of therapist & Study location & Methodological design \\
\hline Lee, et al; $2013^{(26)}$ & Nurses & Maternity & Randomized clinical trial \\
\hline Miquelutti, et al; $2013^{(27)}$ & Physiotherapist & Maternity & Qualitative study \\
\hline Akbarzadeh,et al; $2014^{(28)}$ & Doulas & Maternity & Randomized clinical trial \\
\hline Reilly, et al; $2014^{(29)}$ & Physiotherapist & Prenatal clinic & Randomized clinical trial \\
\hline Adams, et al; $2015^{(30)}$ & Not informed & Retrospective: database & Longitudinal study \\
\hline Demirel, et al; $2015^{(31)}$ & Not informed & Maternity & Randomized clinical trial \\
\hline Fritel, et al; $2015^{(32)}$ & Physiotherapist or midwives & Prenatal centers & Randomized clinical trial \\
\hline Gayeski, et al; $2015^{(5)}$ & Obstetric nurse & Maternity & Cross-sectional \\
\hline Hanjini, et al; $2015^{(33)}$ & Not informed & Maternity & Randomized clinical trial \\
\hline Akbarzadeh, et al; $2016^{(34)}$ & Doulas & Maternity & Randomized clinical trial \\
\hline Boaviagem, et al; $2016^{(35)}$ & Physiotherapists & Maternity & Randomized clinical trial \\
\hline Henrique, et al; $2016^{(36)}$ & Obstetric nurse & Maternity & Randomized clinical trial \\
\hline Karimi, et al; $2016^{(37)}$ & Not informed & Prenatal clinics & Randomized clinical trial \\
\hline Masoumi, et al; 2016 ${ }^{(38)}$ & Midwives & Maternity & Randomized clinical trial \\
\hline Taavoni, et al; $2016^{(39)}$ & Midwives & Maternity & Randomized clinical trial \\
\hline Santana, et al; $2016^{(40)}$ & Physiotherapist & Maternity & Randomized clinical trial \\
\hline Sut, et al; $2016^{(41)}$ & Not informed & Obstetric center & Randomized clinical trial \\
\hline Aziato, et al; $2017^{(42)}$ & Nurse & Tertiary health center & $\begin{array}{l}\text { Qualitative descriptive exploratory } \\
\text { study }\end{array}$ \\
\hline Cicek, et al; 2017 & Not informed & Maternity & Randomized clinical trial \\
\hline Erdogan, et al; $2017^{(44)}$ & Nurses & Maternity & $\begin{array}{l}\text { Experimental study with control } \\
\text { group }\end{array}$ \\
\hline Miquelutti, et al; $2017^{(45)}$ & Physiotherapist and Obstetrician & Maternity & Randomized clinical trial \\
\hline Shahoei, et al; $2017^{(46)}$ & Midwives & Maternity & Clinical study \\
\hline Vanderlaan, et al; $2017^{(47)}$ & Nurses and midwives & Maternity & Retrospective cohort study \\
\hline Yuksel, et al; $2017^{(48)}$ & Not informed & Maternity & Randomized clinical trial \\
\hline Ugwu, et al; 2018 ${ }^{(49)}$ & Self-applicable & Prenatal clinics & Randomized clinical trial \\
\hline
\end{tabular}

Chart 2 - Description and categorization of NPT.

\begin{tabular}{|c|c|c|}
\hline NPT & Positive outcome & Inconclusive or negative outcome \\
\hline Massage & 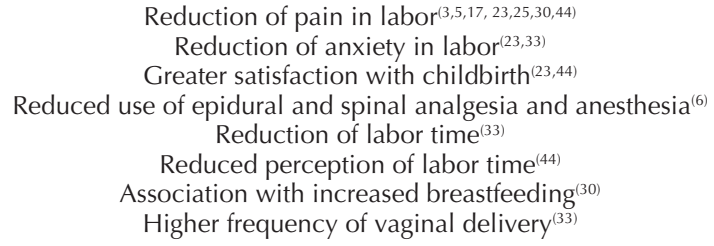 & $\begin{array}{l}\text { Association with increased laceration } \\
\quad \text { and use of forceps }{ }^{(30)} \\
\text { Pain and satisfaction in childbirth }\end{array}$ \\
\hline Perineal massage & $\begin{array}{l}\text { Reduced frequency of episiotomy } y^{(14,20,31)} \\
\text { Reduction of the second stage of labor }{ }^{(20)} \\
\text { Good technique acceptance } \\
\text { Increased incidence of perineal integrity }\end{array}$ & $\begin{array}{l}\text { Increased laceration grades } 1 \text { and } 2^{(20)} \\
\text { No difference regarding postpartum } \\
\text { urinary incontinence }{ }^{(13,22)} \\
\text { No differences regarding perineal trauma } \\
\text { in general }\left.\right|^{(13,21)}\end{array}$ \\
\hline Hot bath & 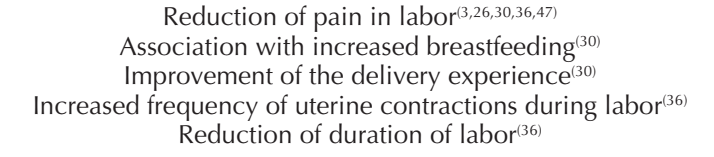 & $\begin{array}{l}\text { Associated with increased laceration }{ }^{(30)} \\
\text { Increased fetal heart rate }{ }^{(36)}\end{array}$ \\
\hline
\end{tabular}




\begin{tabular}{|c|c|c|}
\hline NPT & Positive outcome & Inconclusive or negative outcome \\
\hline Supportive care & $\begin{array}{l}\text { Reduction of pain in labor }{ }^{(23,28)} \\
\text { Increased incidence of vaginal delivery } \\
\text { Reduction of duration of labor }{ }^{(34)} \\
\text { Resulted in Apgar scores greater than } 8^{(34)} \\
\text { Reduction of anxiety }\end{array}$ & \\
\hline $\begin{array}{l}\text { Childbirth preparation } \\
\text { groups }\end{array}$ & $\begin{array}{l}\text { Control of anxiety and feeling of security } \\
\text { Increased comfort and mobility during childbirth } \\
\text { Increased satisfaction with childbirth } \\
\text { Reduction of fear of vaginal delivery } \\
\text { Reduction of anxiety } \\
\text { Increased positive thinking } \\
\text { Increased choice of vaginal delivery } \\
\text { Higher rates of non-instrumental delivery) } \\
\text { Higher weight of the baby }{ }^{(37-38)}\end{array}$ & $\begin{array}{l}\text { Childbirth experience } e^{(14)} \\
\text { Use of analgesia }{ }^{(14)} \\
\text { Stress in maternity }{ }^{(14)}\end{array}$ \\
\hline Breathing techniques & $\begin{array}{l}\text { Reduction of pain }{ }^{(3,43,48)} \\
\text { Reduction of duration of labor } \\
\text { Reduction of anxiety in labor }{ }^{(43)}\end{array}$ & $\begin{array}{c}\text { There was no difference for anxiety, } \\
\text { pain, fatigue, satisfaction, type of } \\
\text { delivery, duration of labor and Apgar } \\
\text { scores }^{(35)}\end{array}$ \\
\hline Pelvic floor exercises & $\begin{array}{l}\text { Less susceptibility to urinary incontinence in the postpartum period }{ }^{(29)} \\
\qquad \text { Increased pelvic floor muscle strength }^{(41)}\end{array}$ & $\begin{array}{l}\text { Postpartum urinary incontinence }{ }^{(32)} \\
\text { Type of delivery, frequency of perineal } \\
\text { laceration and neonatal variables }{ }^{(18)}\end{array}$ \\
\hline TENS & $\begin{array}{l}\text { Reduction of pain in labor }{ }^{(16,40,46)} \\
\text { Postponement of the use of epidural analgesia }{ }^{(40)} \\
\text { Reduced postpartum blood loss }\end{array}$ & \\
\hline Swiss ball & $\begin{array}{c}\text { Reduction of pain in labor }{ }^{(19,39)} \\
\text { Increased confidence in relation to labor }{ }^{(19)} \\
\text { Reduction of duration of labor } \\
\text { Increased frequency of uterine contractions during labor }{ }^{(36)}\end{array}$ & Increased fetal heart rate ${ }^{(36)}$ \\
\hline Spontaneous pushing & Reduction in the incidence of perineal laceration ${ }^{(22)}$ & Postpartum urinary incontinence ${ }^{(22)}$ \\
\hline
\end{tabular}

Legend: NPT: non-pharmacological therapies; TENS: transcutaneous electrostimulation.

\section{DISCUSSION}

From the analysis of the 41 articles, ten NPT that presented positive outcomes for labor, childbirth and the puerperium were identified, namely pain relief, increase of women's positive thinking, reduction of anxiety, duration of labor, perineal lacerations and postpartum urinary incontinence (UI). This study believes that NPT allow the qualification of care to women through non-invasive relief measures that stimulate their active participation in the gestational process and provide them with more knowledge.

In the articles included in this review, NPT applied in a hospital setting predominated. Thus, 30 (73.17\%) studies presented therapies in the maternity, of which seven (17\%) were conducted in Brazil, demonstrating that Brazilian practices have sought alignment with those of other countries and more humanized and evidence-based obstetric care ${ }^{(50)}$. Ten (24.39\%) studies brought the application of NPT in childbirth preparation clinics with techniques that needed a longer follow-up to obtain positive outcomes, such as childbirth preparation groups, perineal massage and $\mathrm{PF}$ exercises ${ }^{(14,32,49)}$. Only one (2.44\%) retrospective study used data from a previously collected database ${ }^{(30)}$. The practice of NPT in labor allows pregnant women to have more knowledge of puerperal-pregnancy processes, thereby making them more confident at the time of delivery, reducing anxiety, stress and, consequently, pain ${ }^{(27)}$.

As for professionals who apply the NPT, four professions were identified in this review; midwives were present in 11 (26.89\%) articles, nurses in ten (24.39\%), physiotherapists in nine (21.95\%) and doulas in two (4.87\%). In ten $(24.39 \%)$ studies, the therapist's profession was not informed, and of these, four described that the researchers applied the therapies without identifying another specific profession $^{(37,41,43,48)}$ and two used data from routine services in maternity hospitals ${ }^{(6,30)}$. The prevalence of midwives in international publications is due to the recognition of this profession in the care of pregnant women and childbirth $^{(12,17,20,24,32,43,50)}$. In Brazil, where nurses and physiotherapists prevailed, although the training of midwives is not a conventional practice yet, it is gradually coming back, in the opposite direction of the biomedical model ${ }^{(18,25,36,50)}$. The participation of this professional reflects the concern with comprehensive care and the search for the return of women as protagonists in childbirth with the decentralization of the physician's role and less obstetric interventions. In the same direction, the prevalence of nurses and physiotherapists in the national scenario is the result of the search for a comprehensive health model, based on the guidelines of these professions ${ }^{(51-52)}$. Nurses are the professionals who accompany women throughout the puerperal-pregnancy period and the first contact with women's health care ${ }^{(53)}$. The presence of nurses in the scenario of pregnancy, labor and childbirth providing care to women justifies the number of studies bringing these professionals as those who apply therapies. In addition, physiotherapy is the science of active movement that believes in body movement as a way 
to reduce the negative effects of pregnancy and labor ${ }^{(54)}$. The participation of the physiotherapist in pregnancy and labor processes as a member of the interdisciplinary team is an increasing trend in studies and should be valued ${ }^{(2,45)}$. This review demonstrates that, regardless of the therapist's profession, the multidisciplinary team acts in the practice of NPT and in the care of women during pregnancy and labor, and the association of professions that assist women during childbirth is increasingly present in the studies.

Women's view on childbirth was also addressed in a study that did not present any specific intervention, but offered a view on their experience and perception of pain and how it is multifactorial ${ }^{(42)}$. The study cited women's views on pharmacological and non-pharmacological interventions and how immobility does not reduce pain. In the reports, the analgesic measures received reduced the perception of pain, but resulted in the need for other doses to maintain analgesia, which can lead to longer duration of labor because of the reduction in uterine contractions and women's movement. The study suggests that interventions for pain relief in labor should be chosen by the woman thus, their prior knowledge of pharmacological and non-pharmacological analgesic measures is important ${ }^{(42)}$. Listening to women's opinion is important, as it allows health professionals to know the side of the protagonist of childbirth and assess if their interventions have been really effective at the time of delivery.

In this sense, two (4.87\%) studies addressed the satisfaction or experience of women in relation to the NPT received, pointing to a gap in the literature regarding the number of qualitative studies considering the pregnant woman's view on therapies applied during pregnancy, labor and delivery ${ }^{(27,42)}$. One believes that addressing the experiences of pregnant and puerperal women in relation to NPT is essential to reaffirm which therapies improve the experience of childbirth from women's perspective, encouraging their role in the puerperalpregnancy process.

The use of Kinesio taping, an elastic bandage placed in the region of the lumbar spine to reduce labor pain, was evaluated in a study that did not show results and did not make clear the reason for its absence ${ }^{(45)}$. Although the study fulfilled the criteria to be included in this study, Kinesio taping is not a non-pharmacological therapy included and recommended in this review, given the lack of results proving the effectiveness of the technique, as well as the scarce literature justifying its use in labor, corroborating the study found.

Similarly, one study ${ }^{(22)}$ analyzed the use of spontaneous pushing to reduce UI in the postpartum period and found no significant differences. Spontaneous pushing is recommended to avoid pelvic floor lacerations ${ }^{(22)}$. Despite the small amount of evidence found in this review on spontaneous pushing, one recommends its use because it allows women to control the moment of delivery and the expulsive period. Unlike Kinesio taping, spontaneous pushing is already used and recommended in the second stage of labor to prevent perineal trauma and to facilitate delivery ${ }^{(55)}$.

As for the most used NPT during pregnancy and labor, massage and perineal massage were the most prevalent, and demonstrated positive results in most studies. Massage was one of the most used interventions among studies; in ten $(24.39 \%)$ articles, the intervention was used in pregnancy and in labor to assess different variables ${ }^{(3,5-6,30,33,44)}$. Pain was the main variable analyzed in these studies. The assumption of pain reduction by massage can be explained by the Gate Control Theory, in which the stimulation of thicker peripheral fibers, such as therapeutic touch, inhibits painful stimuli in the central nervous system, reducing pain ${ }^{(6)}$. A similar mechanism is recognized in TENS ${ }^{(9)}$.

Massage can also stimulate the parasympathetic system, responsible for anxiety control responses, consequently increasing the maintenance of breastfeeding by mothers ${ }^{(30)}$. Similarly, studies show that the association of massage and breathing techniques reduces fear and anxiety and, consequently, reduces pain even more ${ }^{(12,30)}$. The pain-anxiety-pain cycle can be broken with the use of massage, increasing women's feelings of control and satisfaction with motherhood ${ }^{(12)}$.

It is important to consider the body as a whole, and an intervention based on a motor mechanism of tissue release and pain relief generates positive consequences [relief] in anxiety and fear and positive results in childbirth. In a study that did not achieve significant differences between groups, there was a reduction in pain and higher satisfaction with childbirth in the group that received the massage, confirming the previous statement ${ }^{(12)}$. Different massage techniques were applied in the studies, and the most common was massage in the lumbosacral region, which is the most painful during labor ${ }^{(3,5,12,25)}$. In other studies, a more global massage in different regions of the body was described, according to the woman's desire ${ }^{(6,17,24)}$. A study brought the application of massage on the foot sole, a technique known as reflexology, and the authors reported the local benefits of the massage, such as muscle relaxation, increased blood circulation and the overall benefits, such as feelings of comfort and mental balance, thereby reducing stress symptoms ${ }^{(33)}$.

During the massage, endorphins and enkephalins, natural painkillers that reduce pain and improve mood, are released. The results of reflexology proved to be more positive, since the author evaluated pain, labor duration and Apgar scores and obtained a positive result for the intervention group in the three variables ${ }^{(33)}$.

Studies defend massage as a simple and inexpensive method, easy to apply, which can be taught during pregnancy and applied by the partner, thus a simple measure for women's support that makes labor more humanized ${ }^{(23,25)}$. Although no qualitative studies reporting the woman's experience in relation to massage as a therapeutic intervention for pregnancy and labor were found, the study that evaluated women's satisfaction with the use of massage obtained positive results ${ }^{(5)}$. A Cochrane review confirmed our findings of pain reduction through massage ${ }^{(1)}$.

Perineal massage works to stretch the muscles of the pelvic floor, facilitating the passage of the fetus through the vagina, reducing the pain caused by perineal stretching in childbirth and the risk of perineal injury. This therapy was addressed by seven (17.07\%) articles in this review ${ }^{(13,21-22,24,49)}$. Women who underwent perineal massage during labor had a 
lower frequency of episiotomy ${ }^{(20,31)}$. A study has shown that, although well accepted by pregnant women, few are aware of the technique that could be self-applied if properly taught ${ }^{(24)}$. Increased awareness of the perineum during pregnancy is part of a strategy to promote the integrity and protection of the region during pregnancy and puerperal period ${ }^{(24)}$.

The results of studies have shown that perineal massage does not have a protective effect on the pelvic floor, does not increase the frequency of perineal integrity after delivery and also has no effect on the frequency of urinary and fecal incontinence postpartum ${ }^{(13,21-22)}$. Similarly, a Cochrane review concluded that perineal massage does not reduce the frequency of episiotomy and lacerations grade 1 and 2, but has a positive effect in reducing grade 3 and 4 lacerations ${ }^{(8)}$. A recent study demonstrated its efficiency in maintaining an intact perineum in the postpartum period ${ }^{(49)}$. Thus, the use of perineal massage from the $34^{\text {th }}$ week of pregnancy is recommended for stretching the perineum and avoiding more severe pelvic floor lacerations, as a knowledge tool and for increased perception of the mode of delivery. An advantage of this technique is the possibility of self-application that facilitates its use by women during pregnancy ${ }^{(13,49)}$.

Five (12.19\%) studies brought the hot bath as a NPT used in labor ${ }^{(3,26,30,36,47)}$. The hot bath and hydrotherapy are therapeutic interventions widely used in clinical practice, with positive results in reducing pain in labor, but few studies analyzing the effects of hot bath in labor have been found.

A study that evaluated several NPT during labor found that the hot bath can reduce the admission of babies to the intensive care unit and increase adherence to breastfeeding ${ }^{(30)}$. However, an unfavorable result was found regarding the increase in the frequency of perineal laceration. In another study, the use of hot baths proved to be efficient in reducing the pain caused by the dilation ${ }^{(3)}$. The association of the hot bath with other techniques, such as the Swiss ball and perineal exercises, was more efficient in reducing the perception of pain and the duration of labor ${ }^{(36)}$.

Similar to massage, the principle of pain reduction with the hot bath follows the Gate Control Theory, because the hot bath stimulates the skin thermoreceptors, which reach the brain faster than painful stimuli, thereby blocking the painful response and perception ${ }^{(26,47)}$. The intervention performed in these studies followed the protocol of hot baths at a temperature of $37^{\circ} \mathrm{C}$ for 20 to 30 minutes or indefinitely ${ }^{(26,36,47)}$.

Despite the positive effects of the hot bath in the studies, there is still little evidence proving its effectiveness in pain relief and other variables of labor. No publications bringing the woman's experience with regard to its use in labor were found. Thus, for a more frequent use of hot baths, more studies need to be developed.

Supportive care was a therapeutic intervention found in three (7.31\%) studies in this review. This category includes all the monitoring provided to pregnant women during labor and involves therapeutic touch, emotional support, offering understanding for the pregnant woman, and the use of pain relief techniques such as massage and mobilization $^{(23,28,34)}$. This care is considered a therapeutic pain relief intervention, since it is a multifactorial experience involving the mechanical mechanism of painful stimulus, the emotional experience and activation of the limbic system, leading to a physical perception. Since pain can be sensory, emotional and cognitive, it requires an intervention addressing the three dimensions, defined by the authors as supportive care $^{(34)}$.

Supportive care is also considered a mechanical intervention, because it involves changes of posture during labor, accelerating the progression of childbirth and reducing pain $^{(34)}$. For the role of support to the parturient woman, in addition to health professionals, the doula was mentioned as a reference, playing an important role, supporting, comforting and encouraging the pregnant woman to move during labor. In two articles this therapy was used as an intervention, variables of childbirth and baby were analyzed, and both obtained positive results in reducing pain, reducing the duration of labor and the frequency of Apgar scores greater than eight ${ }^{(28,34)}$. Similarly, other authors analyzed the experience of women in relation to supportive care and obtained positive results in reducing anxiety and pain, making the experience of childbirth more pleasant ${ }^{(23)}$. Thus, the use of supportive care is recommended to give more confidence, independence and positive emotional support to the woman during labor. Although it is considered a combination of therapies, its use proved to be efficient as a tool to help pregnant women in labor. In this review, the combination of physical and psychological techniques is considered effective in facilitating childbirth and a positive experience for women.

Similar to supportive care, childbirth preparation groups work on the integrality of women, bring non-pharmacological interventions for pain relief, emotional and psychological control techniques and information on childbirth and motherhood. In these groups, the partner can be encouraged to take the place of support caregiver, increasing the bond and comfort of the pregnant woman ${ }^{(14-15)}$.

Six $(14.63 \%)$ articles that used childbirth preparation groups $^{(14-15,27,37,43)}$ as an intervention were found. These groups can help the woman and her partner to adapt to motherhood, increase the woman's vitality and positive thinking during pregnancy, labor and childbirth, and reduce the emotional factors of pain, stress and anxiety ${ }^{(15)}$. In contrast, in another study, the benefits brought by these groups to childbirth and the puerperal period were not evident, since there were no differences between groups regarding the use of analgesia and the experience of motherhood ${ }^{(14)}$.

Two publications analyzed the influence of preparation groups in the choice for the type of delivery, in the baby's weight and in reducing the fear of labor, obtaining favorable results for the intervention group, with greater choice for vaginal delivery and greater weight of babies ${ }^{(37-38,43)}$. They also demonstrated that childbirth preparation groups are important tools to reduce women's fear of natural childbirth ${ }^{(37-38)}$. The results of studies lead to the conclusion that this intervention increases women's knowledge about the processes of childbirth and motherhood, which generates positive thinking, reduces natural fear and increases the choice for vaginal delivery, with beneficial consequences for the baby. 
In a study, women's perceptions of childbirth preparation programs were analyzed, and they responded positively about their experience with the program. Participants reported more control in labor, control of anxiety, feeling of security, greater ease of movement and satisfaction with the experience of childbirth ${ }^{(27)}$. Although different variables were addressed in the studies, it is a consensus that preparation groups assist in the emotional and psychological maturation of women, increase their confidence and the feeling of control ${ }^{(15,27,37,43)}$.

Four (9.75\%) articles in this review used breathing techniques as an intervention. Two out of these reported a positive effect on anxiety, duration of labor and pain reduction ${ }^{(43,48)}$. The other two studies attested that using combined techniques may be more efficient in reducing pain than only breathing techniques ${ }^{(3,35)}$.

Respiratory techniques consist of coordinated breathing exercises that may follow different protocols, such as prolonged breathing, diaphragmatic breathing, nasal inspiration and pursed-lip breathing, among others. Breathing control reduces anxiety and increases self-control, reduces pain and facilitates fetal descent, helping with labor. Although the mechanism is known, more studies are needed to confirm the effectiveness of breathing techniques in pregnancy and childbirth, which does not prevent its use associated with other techniques $\mathrm{s}^{(3,35,43)}$.

Similar to perineal massage, pelvic floor exercises during pregnancy increase the woman's perception of this musculature, increase blood circulation and strengthen this region ${ }^{(32)}$. Four $(9.75 \%)$ articles evaluated the effect of these exercises in the puerperal pregnancy period ${ }^{(18,29,32)}$. The aim of one of the articles was to analyze the reduction of UI in the postpartum period through pelvic floor exercises, but there was no difference in results between the groups ${ }^{(32)}$. On the other hand, another study showed a lower incidence of UI in the postpartum period in the group that practiced the exercises ${ }^{(29)}$. The author recommends a prior investigation of women at risk of developing UI due to urethral hypermobility identified by ultrasound, and that pelvic floor exercise programs should be applied to them, showing that there is no need to redirect all women to a specific service for strengthening this musculature ${ }^{(29)}$. One of the articles demonstrates the loss of strength of the pelvic floor during pregnancy and the importance of exercising to reduce such loss, thereby increasing the quality of life and preventing urinary problems ${ }^{(41)}$. Another study analyzed the association between these exercises and the type and duration of delivery, but did not find a positive or negative association, thus, these exercises are safe to be performed during pregnancy ${ }^{(18)}$.

The practice of pelvic floor exercises can be performed by pregnant women routinely in order to avoid the harmful effects of pregnancy on this musculature. Pregnant women with difficulty in performing pelvic floor exercises should be directed to the specific service for training ${ }^{(29)}$.

The TENS is a unit that sends electrical impulses through electrodes placed on the skin, used for analgesia. During labor, the electrodes are placed on the dermatomes responsible for uterine and pelvic floor innervation. As previously mentioned, the TENS analgesia mechanism is similar to that of massage, from the Gate Control Theory, associated with endorphin release that acts as a natural analgesic ${ }^{(6)}$.

Three (7.31\%) articles included in this review found a positive effect of the use of TENS in reducing pain in labor, which was recommended without producing harmful effects for the baby. It can be used according to the comfort of the pregnant woman in high or low frequency for periods starting from 15 minutes $^{(16,40,46)}$. In a Cochrane review, although the conclusion was that there is still no evidence proving the positive effect of TENS in reducing pain in labor, its offer as a non-pharmacological method of pain relief during this period was recommended ${ }^{(7)}$.

The use of the Swiss ball during pregnancy and labor aims to increase pelvic mobility and facilitate the descent of the fetus, just like the adoption of vertical postures by the woman, reducing the time of labor, promoting pain relief and increasing the pregnant woman's independence. Using the ball during pregnancy promotes postural alignment, greater perception of the body and of changes in the center of gravity, reduces pelvic back pain and increases the woman's confidence and mobility during labor ${ }^{(19)}$.

Three $(7.31 \%)$ studies in this review showed a positive result in the use of the Swiss ball during pregnancy and labor, because there was a reduction of pain and of the duration of this period ${ }^{(36,19,39)}$. The association between the use of the Swiss ball and the hot bath was efficient to accelerate labor and reduce pain ${ }^{(19,36,39)}$. Different techniques were used in a qualitative study that demonstrated the positive experience of women in relation to vertical positions and movement during labor ${ }^{(27)}$.

The limitation of the present study was the reduced number of articles with qualitative methodological design found in the literature. Since this is an integrative review, the aim was to find more studies addressing the qualitative perspective of NPT. Twenty-eight (68.29\%) studies were randomized clinical trials and evaluated only the quantitative perspective of NPT. For future research, one recommends the search in different databases in order to find more qualitative studies.

\section{CONCLUSION}

The use of NPT was efficient to reduce the negative effects of labor and delivery, such as pain, duration of labor, anxiety, laceration and episiotomy frequency. Therapies such as massage, perineal massage, hot baths and childbirth preparation groups had a greater number of evidences with positive outcomes in labor and delivery and their use by professionals in maternity hospitals is recommended. Nonpharmacological therapies with immediate effects in labor, such as massage, hot baths, TENS, Swiss ball, breathing techniques and supportive care can be used in the maternity routine during labor and delivery. Non-pharmacological therapies that require a longer application period to produce positive effects, such as childbirth preparation groups, perineal massage and pelvic floor exercises should be performed in prenatal clinics. Midwives, nurses and physiotherapists were identified as professionals who apply the therapies, reinforcing the importance of a multidisciplinary team in the care for women in the pregnancy-puerperal cycle. 
RESUMO

Objetivo: Identificar terapias não farmacológicas aplicadas na gestação e no trabalho de parto. Método: Revisão integrativa realizada nas bases de dados: PubMed, ScieLO e PEDro, buscando-se artigos de 2008 nos idiomas inglês, espanhol e português. Os descritores utilizados foram: gravidez, parto, fisioterapia, medicina alternativa e complementar, terapia alternativa, terapia não farmacológica, terapia biomecânica. Resultados: Foram analisados 41 artigos e subdivididos em 10 categorias de terapias não farmacológicas: massagem, massagem perineal, banho quente, cuidado de suporte, grupo de preparação para o parto, técnicas de respiração, exercícios de assoalho pélvico, eletroestimulação transcutânea, bola suíça e puxo espontâneo. Seis artigos (60\%) apresentaram desfecho positivo para redução da dor no trabalho de parto e todos apresentaram algum desfecho positivo para diferentes variáveis do trabalho de parto, como redução do tempo, da ansiedade e das taxas de laceração do assoalho pélvico. Conclusão: $\mathrm{O}$ uso de terapias não farmacológicas foi eficiente para reduzir os efeitos do trabalho de parto e parto, como dor, duração do trabalho de parto, ansiedade, laceração e episiotomia.

\section{DESCRITORES}

Terapias Complementares; Terapia por Exercício; Gestação; Parto Normal; Enfermagem Obstétrica; Revisão.

\section{RESUMEN}

Objetivo: Identificar las terapias no farmacológicas aplicadas durante el embarazo y el parto. Método: Revisión integradora realizada en las bases de datos PubMed, ScieLO y PEDro, buscando artículos de 2008 en inglés, español y portugués. Los descriptores utilizados fueron: embarazo, parto, fisioterapia, medicina alternativa y complementaria, terapia alternativa, terapia no farmacológica, terapia biomecánica. Resultados: Se analizaron 41 artículos y se subdividieron en diez categorías de terapias no farmacológicas: masaje, masaje perineal, baño caliente, cuidados de apoyo, grupo de preparación al parto, técnicas de respiración, ejercicios del suelo pélvico, electroestimulación transcutánea, pelota suiza y pujo espontáneo. Seis artículos (60\%) tuvieron un resultado positivo para la reducción del dolor en el trabajo de parto y todos tuvieron algún resultado positivo para diferentes variables del trabajo de parto, como la reducción del tiempo, la ansiedad y las tasas de laceración del suelo pélvico. Conclusión: El uso de terapias no farmacológicas fue eficaz para reducir los efectos del trabajo de parto y el parto, como el dolor, la duración del trabajo de parto, la ansiedad, la laceración y la episiotomía.

\section{DESCRIPTORES}

Terapias Complementarias; Terapia por Ejercicio; Embarazo; Parto Normal; Enfermería Obstétrica; Revisión.

\section{REFERENCES}

1. Smith CA, Levett KM, Collins CT, Dahlen HG, Suganuma M. Massage, reflexology and other manual methods for pain management in labour. Cochrane Database Syst Rev. 2018;(3):CD009290. doi: 10.1002/14651858.CD009290.pub3

2. Nunes GS, Souza PCM, Vial DSV. Recursos fisioterapêuticos para o alívio da dor no trabalho de parto. Rev Faipe [Internet]. 2017 [citado 2018 jul. 16];5(1):90-9. Disponível em: http://www.revistafaipe.com.br/index.php/RFAIPE/article/view/51

3. Davim RMB, Torres GV, Dantas JC. Effectiveness of non-pharmacological strategies in relieving labor pain. Rev Esc Enferm USP [Internet]. 2009 [cited 2018 March 03]; 43(2):438-41. Available from: http://www.scielo.br/pdf/reeusp/v43n2/a25v43n2.pdf

4. Hajiamini Z, Masoud SN, Ebadi A, Mahboubh AE, Matin AA. Comparing the effects of ice massage and acupressure on labor pain reduction. Complement Ther Clin Pract. 2012;18:169-72. doi: https://doi.org/10.1016/j.ctcp.2012.05.003

5. Gayeski ME, Brüggemann OM, Monticelli M, Santos EKA. Application of nonpharmacologic methods to relieve pain during labor: the point of view of primiparous women. Pain Manag Nurs. 2015;16(3):273-84. doi: 10.1016/j.pmn.2014.08.006

6. Dhany AL, Mitchell T, Foy C. Aromatherapy and massage intrapartum service impact on use of analgesia and anesthesia in women in labor: a retrospective case note analysis. J Altern Complement Med. 2012;18(10):932-8. doi: 10.1089/acm.2011.0254

7. Dowswell T, Bedwell C, Lavender T, Neilson JP. Transcutaneous electrical nerve stimulation (TENS) for pain relief in labour. Cochrane Database Syst Rev. 2009;(2):CD007214. doi: 10.1002/14651858.CD007214.pub2

8. Aasheim V, Nilsen ABV, Reinar LM, Lukasse M. Perineal techniques during the second stage of labour for reducing perineal trauma. Cochrane Database Syst Rev. 2017;(6):CD006672. doi: 10.1002/14651858.CD006672.pub2

9. Jones L, Othman M, Dowswell T, Alfirevic Z, Gates S, Newburn M, et al. Pain management for women in labour: an overview of systematic reviews. Cochrane Database Syst Rev. 2012;(3):CD009234. doi: https://doi.org/10.1002/14651858.CD009234.pub2

10. Cristmals CD, Gross JJ. An integrative literature review framework for postgraduate nursing research reviews. Eur J Res Med Sci. 2017;5(1):715.

11. Whittemore R, Knafl K. The integrative review: updated methodology. J Adv Nurs. 2005;52:546-53. doi: http://doi.org/10.1111/j.13652648.2005.03621.x

12. Kimber L, McNabb M, McCourt C, Haines A, Brocklehurst P. Massage or music for pain relief in labour: a pilot randomised placebo controlled trial. Eur J Pain. 2008;12(8):961-9. doi: 10.1016/j.ejpain.2008.01.004

13. Mei-dan E, Walfisch A, Raz I, Levy A, Hallak M. Perineal massage during pregnancy: a prospective controlled trial. Isr Med Assoc J. 2008;10(7):499-502.

14. Bergström M, Kieler H, Waldenström U. Effects of natural childbirth preparation versus standard antenatal education on epidural rates, experience of childbirth and parental stress in mothers and fathers: a randomised controlled multicentre trial. BJOG. 2009;116(9):116776. doi: 10.1111/j.1471-0528.2009.02144.x

15. Bahadoran P, Asefi F, Oreyzi H, Valiani M. The effect of participating in the labor preparation classes on maternal vitality and positive affect during the pregnancy and after the labor. Iran J Nurs Midwifery Res [Internet]. 2010 [cited 2018 Dec 10];15 Suppl1:331-6. Available from: https://www.ncbi.nlm.nih.gov/pmc/articles/PMC3208940/

16. Peng T, Li XT, Zhou SF, Xiong Y, Kang Y, Cheng HD. Transcutaneous electrical nerve stimulation on acupoints relieves labor pain: a nonrandomized controlled study. Chin J Integr Med. 2010;16(3):234-8. doi: 10.1111/jog.12345 
17. Taghinejad H, Delpisheh A, Suhrabi Z. Comparison between massage and music therapies to relieve the severity of labor pain. Womens Health (Lond). 2010;6(3):377-81. doi: /10.2217/WHE.10.15

18. Dias LAR, Driusso P, Aita DLCC, Quintana SM, Bø K, Ferreira CHJ. Effect of pelvic floor muscle training on labour and newborn outcomes: a randomized controlled trial. Rev Bras Fisiot. 2011;15(6):487-93. doi: 10.1590/S1413-35552011005000011

19. Gau ML, Chang CY, Tian SH, Lin KC. Effects of birth ball exercise on pain and self-efficacy during childbirth: a randomised controlled trial in Taiwan. Midwifery. 2011;27(6):e293-300. doi: 10.1016/j.midw.2011.02.004

20. Geranmayeh M, Habibabadi ZR, Fallahkish B, Farahani MA, Khakbazan Z, Mehran A. Reducing perineal trauma through perineal massage with vaseline in second stage of labor. Arch Gynecol Obstet. 2012;285(1):77-81. doi: 10.1007/s00404-011-1919-5

21. Karaçam Z, Ekmen H, Calişir H. The use of perineal massage in the second stage of labor and follow-up of postpartum perineal outcomes. Health Care Women Int. 2012;33(8):697-718. doi: 10.1080/07399332.2012.655385

22. Low LK, Miller JM, Guo Y, Ashton-Miller JA, DeLancey JOL, Sampselle CM. Spontaneous pushing to prevent postpartum urinary incontinence: a randomized, controlled trial. Int Urogynecol J. 2013;2(3):453-60. doi: 10.1007/s00192-012-1884-y

23. Mortazavi SH, Khaki S, Moradi R, Heidari K, Rahimparvar SFV. Effects of massage therapy and presence of attendant on pain, anxiety and satisfaction during labor. Arch Gynecol Obstet. 2012;286(1):19-23. doi: 10.1007/s00404-012-2227-4

24. Ismail SIMF, Emery SJ. Patient awareness and acceptability of antenatal perineal massage. J Obstet Gynaecol. 2013;33(8):839-43. doi: 10.3109/01443615.2013.828027

25. Gallo RBS, Santana LC, Ferreira CHJ, Marcolin AC, PoliNeto OB, Duarte G, et al. Massage reduced severity of pain during labour: a randomised trial. J Physiother. 2013;59(2):109-16. doi: 10.1016/S1836-9553(13)70163-2

26. Lee SL, Liu CY, Gau ML. Efficacy of warm showers on labor pain and birth experiences during the first labor stage. J Obstet Gynecol Neonatal Nurs. 2013;42(1):19-28. doi: 10.1111/j.1552-6909.2012.01424.x

27. Miquelutti MA, Cecatti JG, Makuch MY. Antenatal education and the birthing experience of Brazilian women: a qualitative study. BMC Pregnancy Childbirth. 2013;13:171. doi: 10.1186/1471-2393-13-171

28. Akbarzadeh M, Masoudi Z, Hadianfard MJ, Kasraeian M, Zare N. Comparison of the effects of maternal supportive care and acupressure (BL32 acupoint) on pregnant women's pain intensity and delivery outcome. J Pregnancy. 2014;2014:129208. doi: 10.1155/2014/129208

29. Reilly ETC, Freeman RM, Waterfield AE, Steggles P, Pedlar F. Prevention of pospartum stress incontinence in primigravidae with increased blader neck mobility: a randomized controlled trial of antenatal pelvic floor exercises. BJOG.2014;121 Suppl 7:58-66. doi: https://doi. org/10.1111/1471-0528.13213

30. Adams J, Frawley J, Steel A, Broom A, Sibbritt D. Use of pharmacological and non-pharmacological labour pain management techniques and their relationship to maternal and infant birth outcomes: examination of a nationally representative sample of 1835 pregnant women. Midwifery. 2015;31(4):458-63. doi: https://doi.org/10.1016/j.midw.2014.12.012

31. Demirel G, Golbasi Z. Effect of perineal massage on the rate of episiotomy and perineal tearing. Int J Gynaecol Obstet. 2015;131(2):183-6. doi: https://doi.org/10.1016/j.ijgo.2015.04.048

32. Fritel X, Tayrac R, Bader G, Savary D, Gueye A, Deffieux X, et al. Preventing urinary incontinence with supervised prenatal pelvic floor exercises: a randomized controlled trial. Obstet Gynecol. 2015;126(2):370-7. doi: https://doi.org/10.1097/AOG.0000000000000972

33. Moghimi-Hanjini S, Mehdizadeh-Tourzani Z, Shoghi M. The effect of foot reflexology on anxiety, pain, and outcomes of the labor in primigravida women. Acta Med Iran [Internet]. 2015 [cited 2018 June 10];53(8):507-11. Available from: http://acta.tums.ac.ir/index.php/ acta/article/view/4277

34. Akbarzadeh M, Masoudi Z, Zare N, Kasraeian M. Comparison of the effects of maternal supportive care and acupressure (at BL32 Acupoint) on labor length and infant's apgar score. Glob J Health Sci.2016;8(3):237-44. doi: https://doi.org/10.5539/gjhs.v8n3p236

35. Boaviagem A, Melo Junior E, Lubambo L, Sousa P, Aragão C, Albuquerque S, et al. The effectiveness of breathing patterns to control maternal anxiety during the first period of labor: a randomized controlled clinical trial. Complement Ther Clin Pract. 2017;26:30-5. doi: https://doi.org/10.1016/j.ctcp.2016.11.004

36. Henrique AJ, Gabrielloni MC, Cavalcanti ACV, Melo PS, Barbieri M. Hydrotherapy and the Swiss ball in labor: randomized clinical trial. Acta Paul Enferm. 2016;29(6):686-92. doi: http://dx.doi.org/10.1590/1982-0194201600096

37. Karimi S, Kazemi F, Masoumi SZ, Shobeiri F, Roshanaei G. Effect of consultation and educating in preparation classes for delivery on pregnancy consequences: a randomized controlled clinical trial. Electron Physician. 2016;8(11):3177-83. doi: http://dx.doi. org/10.19082/3177

38. Masoumi SZ, Kazemi F, Oshvandi K, Jalali M, Esmaeli-Vardanjani A, Rafiei H. Effect of training preparation for childbirth on fear of normal vaginal delivery and choosing the type of delivery among pregnant women in Hamadan, Iran: a randomized controlled trial. J Family Reprod Health [Internet]. 2016 [cited 2016 Sep 10];1(3):115-21. Available from: https://www.ncbi.nlm.nih.gov/pmc/articles/PMC5241355/

39. Taavoni S, Sheikhan F, Abdolahian S, Ghavi F. Birth ball or heat therapy? A randomized controlled trial to compare the effectiveness of birth ball usage with sacrum-perineal heat therapy in labor pain management. Complement Ther Clin Pract. 2016;24:99-102. doi: https:// doi.org/10.1016/j.ctcp.2016.04.001

40. Santana LS, Gallo RBS, Ferreira CHJ, Duarte G, Quintana SM, Marcolin AC. Transcutaneous electrical nerve stimulation (TENS) reduces pain and postpones the need for pharmacological analgesia during labour: a randomised trial. J Physiother. 2016;62(1):29-34. doi: https:// doi.org/10.1016/j.jphys.2015.11.002

41. Sut HK, Kaplan PB. Effect of pelvic floor muscle exercise on pelvic floor muscle activity and voiding functions during pregnancy and the postpartum period. Neurourol Urodyn. 2016;35(3):417-22. doi: https://doi.org/10.1002/nau.22728

42. Aziato L, Acheampong AK, Umoar KL. Labour pain experiences and perceptions: a qualitative study among post-partum women in Ghana. BMC Pregnancy Childbirth. 2017;17:73. doi: https://doi.org/10.1186/s12884-017-1248-1 
43. Cicek S, Basar F. The effects of breathing techniques training on the duration of labor and anxiety levels of pregnant women. Complement Ther Clin Pract. 2017;29:213-9. doi: https://doi.org/10.1016/j.ctcp.2017.10.006

44. Erdogan SU, Yanikkerem E, Goker A. Effects of low back massage on perceived birth pain and satisfaction. Complement Ther Clin Pract. 2017;28:169-75. doi: https://doi.org/10.1016/j.ctcp.2017.05.016

45. Miquelutti MA, Cecatii JG. Kinesio Taping for pain control during labor: protocol of a randomized, controlled trial. Nurs Health Sci. 2017;19(1):95-9. doi: https://doi.org/10.1111/nhs.12321

46. Shahoei R, Shahghebi S, Rezaei M, Naqshbandi S. The effect of transcutaneous electrical nerve stimulation on the severity of labor pain among nulliparous women: a clinical trial. Complement Ther Clin Pract. 2017;28:176-80. doi: https://doi.org/10.1016/j.ctcp.2017.05.004

47. Vanderlaan J. Retrospective cohort study of hydrotherapy in labor. J Obstet Gynecol Neonatal Nurs. 2017:46(3)403-10. doi: https://doi. org/10.1016/j.jogn.2016.11.018

48. Yuksel H, Cayir Y, Kosan Z, Tastan K. Effectiveness of breathing exercises during the second stage of labor on labor pain and duration: a randomized controlled trial. J Integr Med. 2017;15(6):456-61. doi: https://doi.org/10.1016/S2095-4964(17)60368-6

49. Ugwu EO, Iferikigwe ES, Obi SN, Eleje GU, Ozumba BC. Effectiveness of antenatal perineal massage in reducing perineal trauma and post-partum morbidities: a randomized controlled trial. J Obstet Gynaecol Res. 2018;44(7):1252-8. doi: https://doi.org/10.1111/jog.13640

50. Castro CM, Narchi NZ, Lopes GA, Macedo CM, Souza AC. Between the ideal and the possible: initial experiences of midwives in the Unified Health System of São Paulo. Saúde Soc. 2017;26(1);312-23. doi: https://doi.org/10.1590/S0104-12902017162237

51. Brasil. Ministério da Saúde. Portaria n 353, de 14 de fevereiro de 2017. Aprova as Diretrizes Nacionais de Assistência ao Parto Normal. [Internet]. Brasília; 2017 [citado 2018 jun. 14]. Disponível em: https://pesquisa.in.gov.br/imprensa/jsp/visualiza/index.jsp?jornal=1\&dat $a=20 / 02 / 2017$ \&pagina $=37$

52. Driusso P, Rett MT, Meirelles MCCC, Saldanha MES, Zanetti MRD, Ferreira CHJ. Profile of faculty members and of contents of physical therapy in women's health taught in public institutions of higher education in Brazil. Fisiot Pesq. 2017;24(2):211-217. doi: http://dx.doi. org/10.1590/1809-2950/17495424022017

53. Pereira SS, Oliveira ICMS, Santos JBS, Carvalho MCMP. Parto natural: a atuação do enfermeiro diante da assistência humanizada. Tempus Actas Saúde Colet. 2016;10(3):199-213. doi: http://dx.doi.org/10.18569/tempus.v10i3.1727

54. Silva RAB, Rios MJBL, Sousa MD, Lago RBM, Barbosa IS. Physiotherapist performance in the gestational period: an integrative literature review. ReonFacema [Internet]. 2018 [cited 2018 Dec 21];4(4):1330-8. Available from: file:///C:/Users/krysa/Downloads/310-1834-1$\mathrm{PB} \% 20(2) . p d f$

55. World Health Organization. WHO recommendations: intrapartum care for a positive childbirth experience [Internet]. Geneva: WHO; 2018 [cited 2018 Dec 21]. Available from: https://www.who.int/reproductivehealth/publications/intrapartum-care-guidelines/en/ 